\title{
SILVER AND GOLD IONS RECOVERY FROM BATCH SYSTEMS USING Spirulina platensis BIOMASS
}

\author{
ODZYSKIWANIE JONÓW SREBRA I ZLOTA Z ROZTWORÓW \\ Z WYKORZYSTANIEM BIOMASY Spirulina platensis
}

\begin{abstract}
In order to assess ability of Spirulina platensis to recover silver and gold ions from the environment the bioaccumulation of silver and gold ions and their effect on growth, proteins and carbohydrates content of Spirulina platensis biomass was studied. Silver nitrate $\left(\mathrm{AgNO}_{3}\right)$ in concentration range $0.01-1 \mathrm{mg} / \mathrm{dm}^{3}$ and tetrachloroaurate $\mathrm{Na}\left[\mathrm{AuCl}_{4}\right]$ in concentration range $18.5-370 \mathrm{mg} / \mathrm{dm}^{3}$ were added as component of the Spirulina platensis cultivation medium. In case of silver two cultivation media were studied: standard and Cl-free. The process of silver and gold uptake was traced using neutron activation analysis. Presence of silver ions in standard cultivation medium reduced biomass productivity by $66 \%$, while in $\mathrm{Cl}$-free biomass productivity was reduced by $11.8 \%$ only. The reduction of proteins content by $30 \%$ in Cl-free medium and by $19 \%$ in standard medium was also observed. The experiments showed that in case of gold ions loading, the biomass productivity and protein content were reduced only at high $\mathrm{Na}\left[\mathrm{AuCl}_{4}\right]$ concentration in the medium. The behaviour of carbohydrates content change was similar under silver and gold loadings: decrease at low metal concentration followed by increase at high metal concentrations. Scanning electron microscopy allowed observation of spherical metal nanoparticles, which were formed extracellularly during silver and gold bioaccumulation. Spirulina platensis can be used for recovery of precious metals as well as metal nanoparticles production.
\end{abstract}

Keywords: Spirulina platensis, silver, gold, nanoparticles, protein, carbohydrate, neutron activation analysis

\section{Introduction}

In view of rapid development of science and technology demand for critical materials, including precious and rare earth elements, is rapidly rising. Conventional techniques of precious metal mining and recovery are costly, requires consumption of energy, are mainly applicable for high-grade ores and can lead to the environment pollution due to the use of chemicals for metal mobilization and cementation $[1,2]$. Since the volume of high-grade ores is constantly decreasing precious metals recovery from industrial effluent and

\footnotetext{
${ }^{1}$ Institute of Microbiology and Biotechnology, Academiei Str. 1, 2028 Chisinau, R. Moldova

${ }^{2}$ University of Academy of Sciences of Moldova, Academiei Str. 3/1, 2028 Chisinau, R. Moldova

${ }^{3}$ Joint Institute for Nuclear Research, Joliot-Curie Str. 6, 1419890 Dubna, Russia

${ }^{4}$ Horia Hulubei National Institute for R\&D in Physics and Nuclear Engineering, Reactorului Str. 30, MG-6, Bucharest - Magurele, Romania

"Corresponding author: zinikovskaia@mail.ru
} 
bioleaching from low-grade ores in biological way is ecologically and economically acceptable alternative $[1,3]$.

Biosorption and bioaccumulation are two biological processes, which participate in the cycle of matter in the environment. Biosorption is a simple physicochemical surface process, while bioaccumulation is a more complex one, which beside metal sorption on the cell surface includes metal intracellular uptake. In bioaccumulation it is possible to reach lower residual concentration of metals due to higher amount of binding sites and continuous biomass growth [4]. In our previous studies, it was shown that the amount of metals accumulated during the bioaccumulation process was 15-40 times higher than in the biosorption experiments [5, 6]. In case of precious metals their bioaccumulation can be combined with the formation of nanoparticles [7-9].

Cyanobacteria are a large and morphologically diverse group of phototrophic prokaryotes which are found in various habitats. Among cyanobacteria, the Spirulina platensis has drawn more attention because of its unique chemical composition, characterized by high protein and carbohydrates content, along with numerous vitamins, minerals, and carotenoids. Due to its relatively high sorption capacity, Spirulina platensis biomass is increasingly used for removal or recovery of metals from aqueous solutions $[5,10,11]$.

The present study was performed in order to assess (i) silver and gold ions bioaccumulation by the cyanobacterium Spirulina platensis in order to obtain renewable biosorbent; (ii) effect of metal ion on biomass growth and proteins and carbohydrates content; (ii) silver and gold nanoparticles formation during biomass growth.

\section{Material and methods}

\section{Bioaccumulation study}

Spirulina platensis (S. platensis) CNMN-CB-11 was cultivated during 6 days in the laboratory conditions in mineral medium of the following composition: macroelements $\left[\mathrm{g} / \mathrm{dm}^{3}\right]-\mathrm{NaNO}_{3}$ - 2.5; $\mathrm{NaHCO}_{3}$ - 2.0; $\mathrm{NaCl}$ - 1.0; $\mathrm{K}_{2} \mathrm{SO}_{4}$ - 0.6; $\mathrm{Na}_{2} \mathrm{HPO}_{4}$ - 0.2; $\mathrm{MgSO}_{4} \cdot 7 \mathrm{H}_{2} \mathrm{O}-0.2$; and microelements $\left[\mathrm{mg} / \mathrm{dm}^{3}\right.$ medium]: $\mathrm{H}_{3} \mathrm{BO}_{3}-2.86 ; \mathrm{MnCl}_{2} \cdot 4 \mathrm{H}_{2} \mathrm{O}$ 1.81; $\mathrm{CuSO}_{4} \cdot 5 \mathrm{H}_{2} \mathrm{O}-0.08 ; \mathrm{MoO}_{3}-0.015$; FeEDTA $-1 \mathrm{~cm}^{3} / \mathrm{dm}^{3}$. The conditions of laboratory biomass growth were maintained: temperature $23-25{ }^{\circ} \mathrm{C}, \mathrm{pH} \quad 8-10$ and illumination $55 \mu$ moles of photons $/ \mathrm{m}^{2} / \mathrm{s}$. The biomass was cultivated in Erlenmeyer flasks of $300 \mathrm{~cm}^{3}$ volume. The culture was agitated daily, during two hours using the agitator WU-4 at the speed $200 \mathrm{rpm}$.

$\mathrm{AgNO}_{3}$ and $\mathrm{Na}\left[\mathrm{AuCl}_{4}\right]$ solutions were introduced into the medium in the first day of biomass cultivation. Due to the high ability of chloride ions to form insoluble complexes with silver, bioaccumulation experiments with silver ions were performed in standard cultivation medium and in chloride-free medium. Thus, two variants of cultivation medium were used, which contained silver in form of silver ions and as $\mathrm{AgCl}$. Silver nitrate was added in concentration $0.01,0.05,0.1,0.5$, and $1.0 \mathrm{mg} / \mathrm{dm}^{3}$ and $\mathrm{Na}\left[\mathrm{AuCl}_{4}\right]$ in concentrations $18.5,37,74,185$ and $370 \mathrm{mg} / \mathrm{dm}^{3}$. In the stationary growth phase (the sixth day), the cyanobacteria biomass was separated from the culture medium by filtration.

For SEM and NAA, the S. platensis biomass was dried at $105{ }^{\circ} \mathrm{C}$. For biochemical studies, the native biomass was used. Biomass separated from culture medium, was washed with ammonium acetate, to remove salt residues from the biomass surface and was 
re-suspended in distilled water which served as a control. All the experiments were conducted in triplicate and the averages of the measurements for each treatment were used.

\section{Neutron activation analysis (NAA)}

The silver and gold content in biomass was determined by means of neutron activation analysis at the reactor IBR-2, JINR, FLNP (Dubna, Russia). The experimental equipment and irradiation conditions of samples are described elsewhere [12]. Samples were irradiated for 4 days at a neutron flux of $1.8 \times 10^{11} \mathrm{~cm}^{-2} \mathrm{~s}^{-1}$ and their activity was then measured in 4 and 20 days, respectively. The silver content was determined by $\gamma$-line with the energy $657.7 \mathrm{keV}$ of isotope ${ }^{110 \mathrm{~m}} \mathrm{Ag}$ and gold by $\gamma$-line with the energy $411.7 \mathrm{keV}$ of isotope ${ }^{198} \mathrm{Au}$. The NAA data processing and determination of elemental concentrations were performed using Genie 2000 and the software developed at FLNP JINR [13].

\section{Scanning Electron Microscopy (SEM)}

Scanning Electron Microscopy (SEM) was carried out using the Quanta 3D FEG (FEI Company, USA). Operational features of the microscope used in the experiment: magnification 5000-150000x; voltage 1-30 kV.

To estimate the size of the nanoparticles in the obtained SEM micrographs, the points corresponding to the edges of the measured object were determined. For this purpose, the following operations were performed:

(i) the informative signal profile (profile of the color channel intensity distribution) along the straight-line segment passing through the object's borders was created;

(ii) the signal, corresponding to the surroundings of each of the edges (the intensity curve of image pixels along a datum line) was fixed. The edge of the measured object corresponds to the half-height of the Gaussian function, used to describe distribution of the signal intensity;

(iii) the size of the nano-object was determined as the distance between its two edges.

\section{Biochemical analysis of biomass components}

For proteins determination $10 \mathrm{mg}$ of biomass were mixed with $0.9 \mathrm{~cm}^{3} \mathrm{NaOH}$ (concentration $0.1 \mathrm{~N}$ ) for $30 \mathrm{~min} .0 .1 \mathrm{~cm}^{3}$ of the obtained protein extract was mixed with $1.6 \mathrm{~cm}^{3} \mathrm{Na}_{2} \mathrm{CO}_{3}(2 \%)$ in $\mathrm{NaOH} 0.1 \mathrm{~N}, 0.4 \mathrm{~cm}^{3}$ of $\mathrm{CuSO}_{4}(0.5 \%)$ in $\mathrm{Na}_{3} \mathrm{C}_{6} \mathrm{H}_{5} \mathrm{O}_{7}(1 \%)$ and $0.2 \mathrm{~cm}^{3}$ of Folin-Ciocalteu reagent. After $30 \mathrm{~min}$ the absorbance was measured at $750 \mathrm{~nm}$. The protein content was determined using a bovine serum albumin.

To determine carbohydrates content, $0.25 \mathrm{~cm}^{3}$ of the sample was mixed with $2.5 \mathrm{~cm}^{3}$ of Antrone reagent $(0.5 \%)$ in $\mathrm{H}_{2} \mathrm{SO}_{4}(66 \%)$. The mixture was incubated for $30 \mathrm{~min}$ at $100{ }^{\circ} \mathrm{C}$. The absorbance was measured at $620 \mathrm{~nm}$. Carbohydrates content was calculated using a calibration curve for glucose. The content of aforementioned biomolecules was expressed in $\%$ of absolute dry biomass.

\section{Results and discussion}

\section{Silver accumulation}

For prokaryotic organisms silver possesses bactericidal properties in a very low range of concentration. For example, the addition of silver nitrate to chloride-free medium in concentration $10^{-7}-10^{-6} \mathrm{M}$ had no effect on the growth of E. coli. However, cell growth was 
inhibited completely at concentrations of $\mathrm{AgNO}_{3}$ greater than $2.5 \times 10^{-6} \mathrm{M}$ [14]. In spite of the fact that $S$. platensis is less sensible to toxic metal than bacteria this cyanobacterium in question cannot survive at high concentration of toxic metals. Experiments performed on lead, "soft" metal as silver, have shown that low lead concentration in the medium stimulated S. platensis biomass growth but it was drastically reduced (up to $78 \%$ ) at high lead concentrations [11]. Our preliminary experiments performed with silver nitrate concentration up to $1 \mathrm{mg} / \mathrm{dm}^{3}$ have shown that $S$. platensis cannot longer withstand higher silver concentrations.

Thus, the further experiments were conducted at silver nitrate concentration $1 \mathrm{mg} / \mathrm{dm}^{3}$ and lower $\left(0.01,0.05,0.1\right.$, and $\left.0.5 \mathrm{mg} / \mathrm{dm}^{3}\right)$. The amount of silver accumulated by biomass from the media was determined by NAA (Fig. 1).

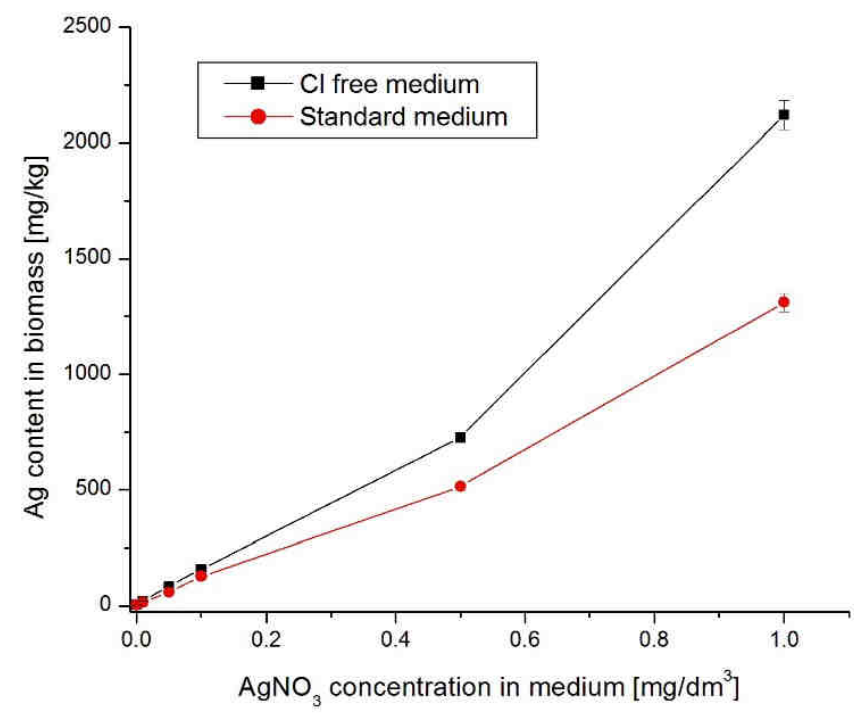

Fig. 1. Silver accumulation by $S$. platensis biomass determined by neutron activation analysis

As it can be seen from the obtained data silver accumulation increased with increase of metal concentrations in the medium. At the concentration range $0.01-0.5 \mathrm{mg} / \mathrm{dm}^{3}$ the amount of silver accumulated by $S$. platensis biomass was almost the same for both media. However, at $\mathrm{AgNO}_{3}$ concentration $1 \mathrm{mg} / \mathrm{dm}^{3}$ the amount of silver accumulated in Cl-free medium $(2.1 \mathrm{mg} / \mathrm{g})$ was approximately 1.5 higher than in the standard medium $(1.3 \mathrm{mg} / \mathrm{g})$.

Very often metal ions bioaccumulation result in the reduction of microbial activity and consequently in biomass growth rate. Thus, the effect of silver ions on the S. platensis productivity was traced (Fig. 2). It can be noted that in the standard medium (Fig. 2) the decrease of biomass productivity by $18 \%$ was observed at $\mathrm{AgNO}_{3}$ concentration $0.1 \mathrm{mg} / \mathrm{dm}^{3}$. Silver nitrate concentrations 0.5 and $1.0 \mathrm{mg} / \mathrm{dm}^{3}$ lead to the reduction biomass productivity by 35 and $66 \%$, respectively. 


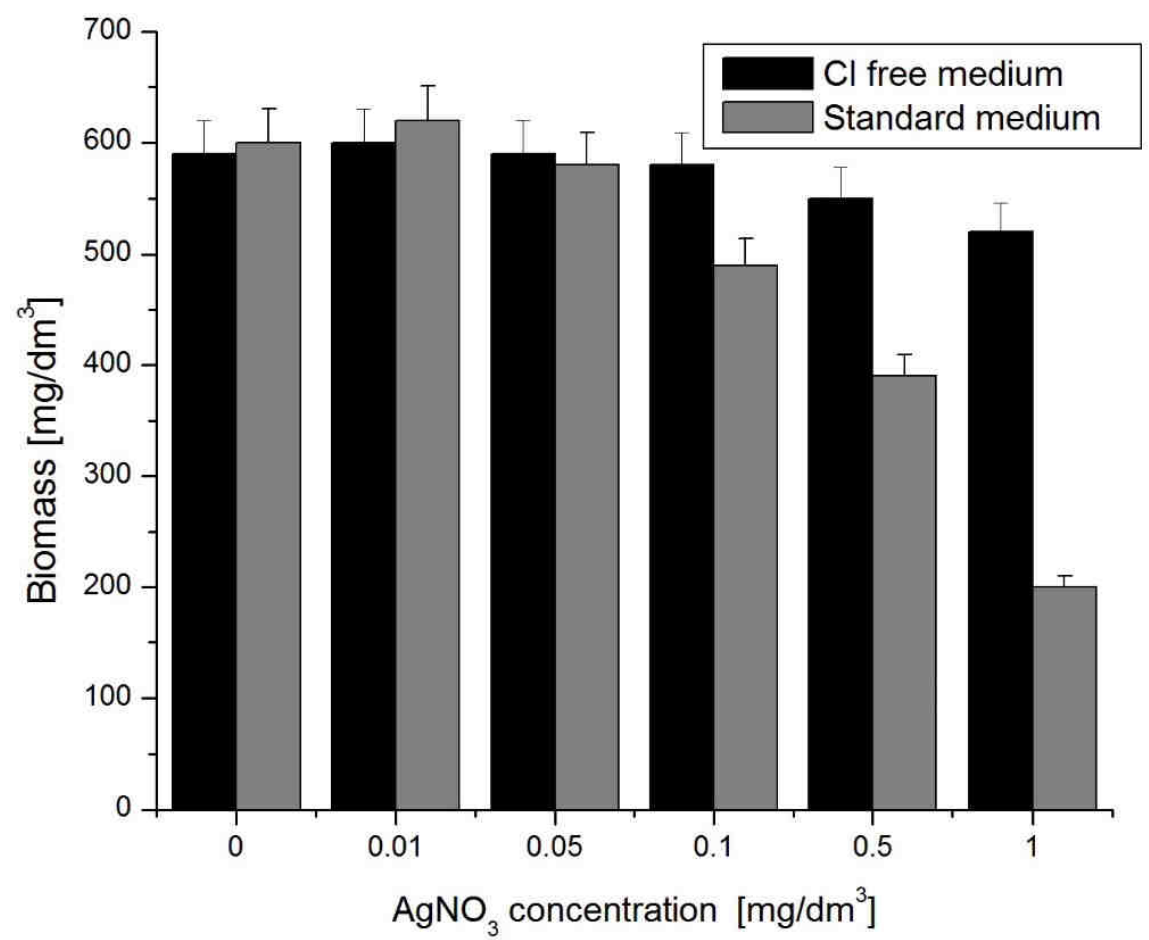

Fig. 2. The effect of different concentrations of $\mathrm{AgNO}_{3}$ on $S$. platensis biomass productivity (mean $\pm S D$, $n=3$ )

Drastic decrease of biomass productivity may be related to (i) formation of $\mathrm{AgCl}$ precipitate that results in chloride ion limitation to the cell [15] or (ii) toxicity of $\mathrm{AgCl}_{0}$ complex. The lack of charge on this complex makes it more easily transported to the site of action [16]. $\mathrm{AgCl}$ bioaccumulation by cyanobacteria can take place through the passive diffusion of $\mathrm{AgCl}_{0}(\mathrm{aq})$ across cell membranes [17]. At the same time in chloride-free cultivation medium (Fig. 2) the concentration of biomass was reduced by $11.8 \%$ only at $\mathrm{AgNO}_{3}$ concentration $1.0 \mathrm{mg} / \mathrm{dm}^{3}$. During the accumulation process a part of silver ions is bound to the specific sites on the cell surface while another part penetrates inside the cell. Fortin et al. [18] suggested that silver ions enter into the cell through a $\mathrm{Cu}(\mathrm{I})$ transport system. $\mathrm{Cu}(\mathrm{I})$ and $\mathrm{Ag}(\mathrm{I})$ possess similar fundamental chemical properties which suggest the possibility of confusion between the two ions by algal transport systems. Once inside silver ions can be reduced to silver nanoparticles.

SEM images obtained for biomass grown till the stationary phase in Cl-free medium revealed extracellular formation of silver nanoparticles (Fig. 3). In standard cultivation medium nanoparticles were not observed. The biosynthesized nanoparticles were almost spherical in aggregates with the average size approximately $30-40 \mathrm{~nm}$, attached to the surface of cells. Our data in agreement with data obtained by other research groups [19, 20]. For example, Tsibakhashvili et al. [20] have shown that $S$. platensis produces silver nanoparticles extracellularly in the range of 5-20 nm with the average size value of $10 \mathrm{~nm}$. 
It is important to mention that in all above mentioned studies of metal nanoparticles synthesis biomass grown until stationary phase was used.

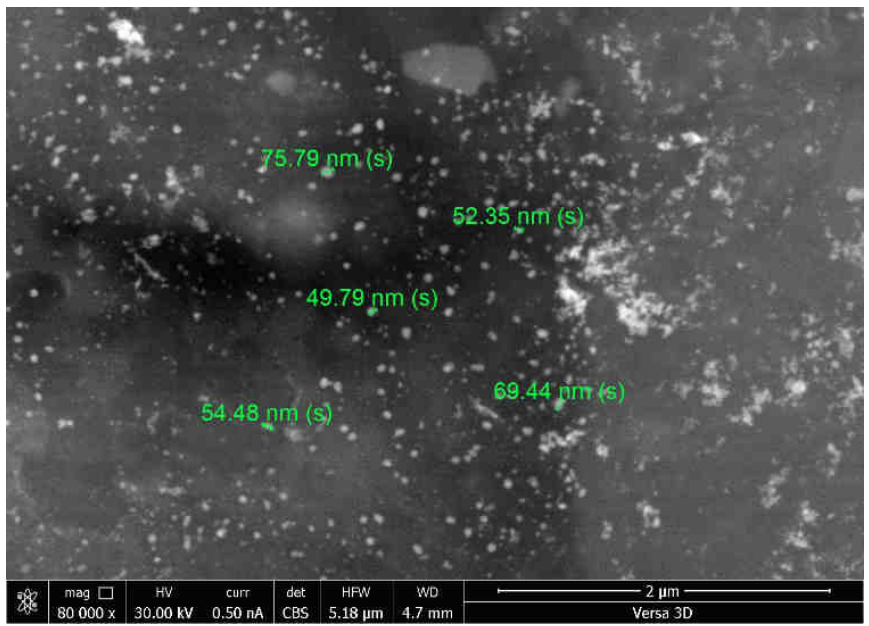

Fig. 3. SEM image of $S$. platensis biomass (Cl-free medium) with silver nanoparticles

While a large number of microbial species are capable of producing metal nanoparticles, the mechanism of nanoparticle biosynthesis is not well understood. The general scheme of nanoparticles formation is very similar for all type of microorganisms: metal ions are first trapped on the surface or inside of the microbial cells. The trapped metal ions are then reduced to nanoparticles in the presence of biomolecules [21]. In case of $S$. platensis biomass silver ions being chemically 'soft' species can binds strongly to proteins and nucleic acids, particularly to cysteine-SH residues and also to amino, imidazole, carboxyl and phosphate groups. Kalishwaralal et al. [22] suggested that the nitrate reductase enzyme is involved in the synthesis of silver nanoparticles in B. licheniformis.

The biochemical composition of the $S$. platensis biomass is the following: proteins $65.8 \%$, carbohydrates $-9.3 \%$, lipids $-5.2 \%$, phycobiliproines $-14.0 \%, \beta$-caroten $-0.3 \%$. The main bioactive compounds are glutamic acid $9.6 \% ; \gamma$-linolenic $1.4 \%$; sulfated polysaccharides - $5.0 \%$, phosfatidylinositol $0.7 \%$, and phosfatidylcholine $1.9 \%$. In stationary culture at the end of the life cycle the biomass quantity reaches values of $1.5-1.6 \mathrm{~g} / \mathrm{dm}^{3}[5]$.

Proteins and carbohydrates are main components of $S$. platensis biomass. Thus, the changes of the proteins and carbohydrates, main components, content during the silver bioaccumulation was monitored. The results obtained are shown in Figures 4 and 5. In the standard cultivation medium (Fig. 4), the decrease of protein content by $19 \%$ was observed only at silver nitrate concentration $1.0 \mathrm{mg} / \mathrm{dm}^{3}$. The protein content in $S$. platensis biomass changed significantly in the $\mathrm{Cl}^{-}$free medium. The highest reduction $(30 \%)$ of protein content was observed at $\mathrm{AgNO}_{3}$ concentration $1.0 \mathrm{mg} / \mathrm{dm}^{3}$, whereas in the cultures exposed to $\mathrm{AgNO}_{3}$ at concentration $0.05,0.1$ and $0.5 \mathrm{mg} / \mathrm{dm}^{3}$ the reduction of the protein content was 12.8, 20 and $22 \%$ respectively. Significant decrease of proteins content can be explained by their involvement in silver nanoparticles production. 


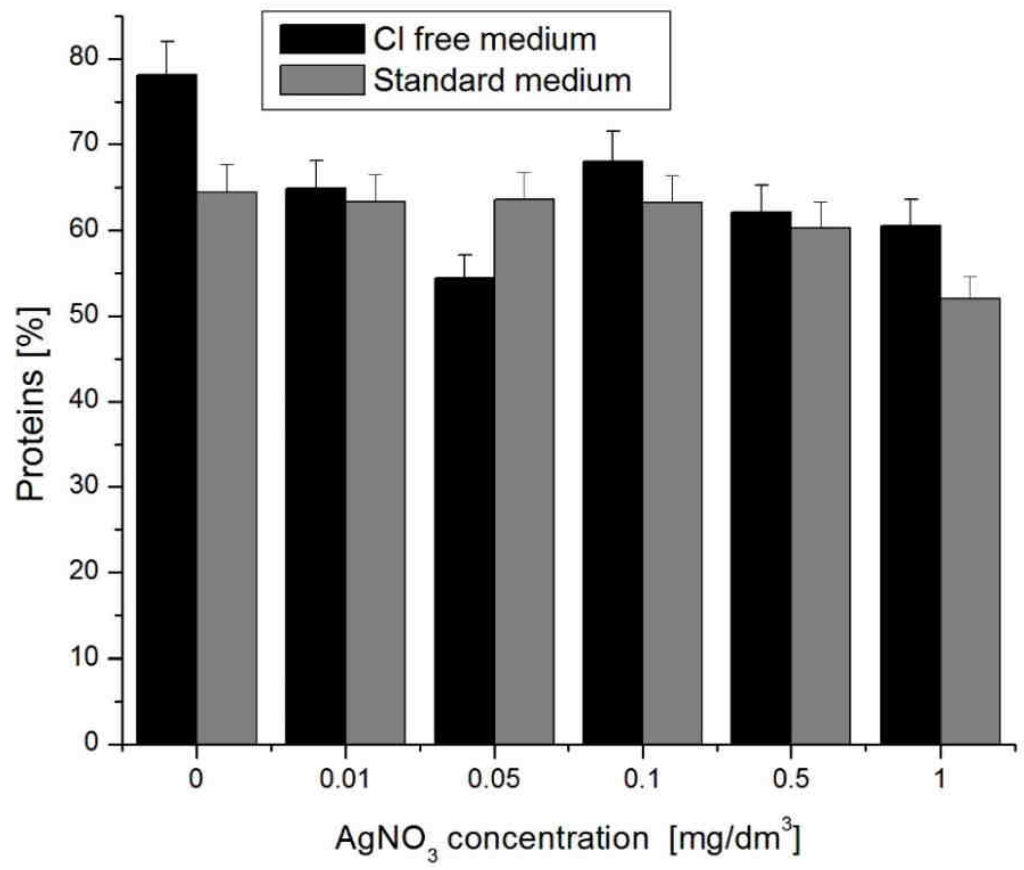

Fig. 4. Change of protein content in $S$. platensis biomass under $\mathrm{AgNO}_{3}$ loading (mean $\pm S D, n=3$ )

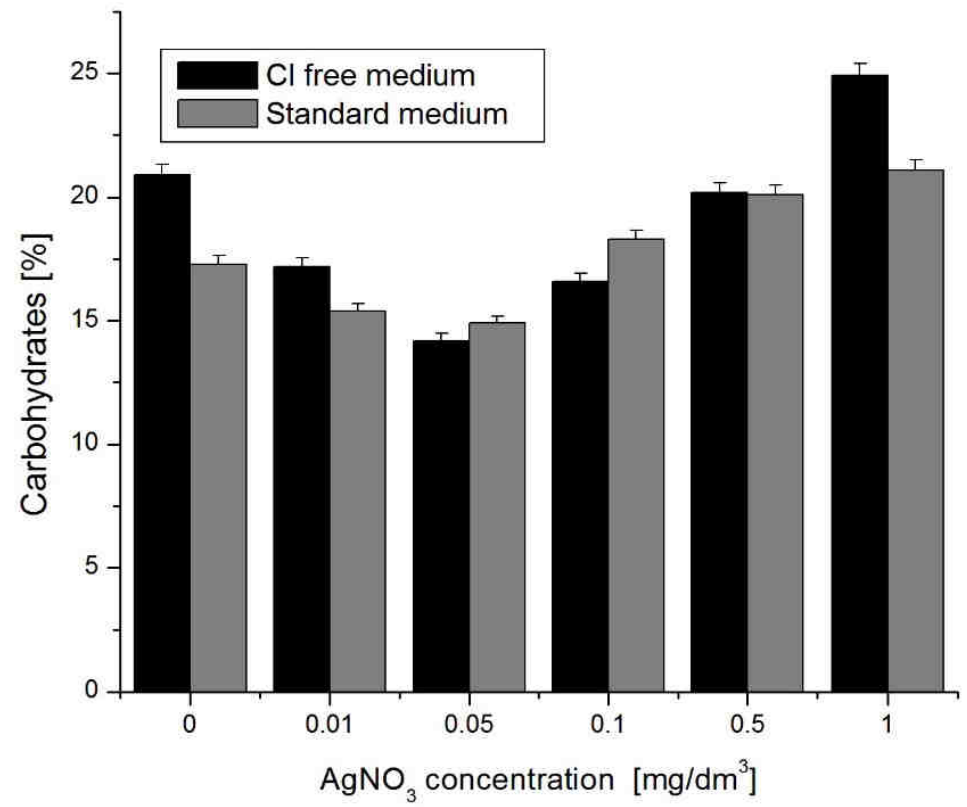

Fig. 5. Change of carbohydrates content in S. platensis biomass under $\mathrm{AgNO}_{3}$ loading (mean $\pm S D$, $n=3$ ) 
In standard cultivation medium (Fig. 5) the content of carbohydrates at $\mathrm{AgNO}_{3}$ concentrations 0.01 and $0.05 \mathrm{mg} / \mathrm{dm}^{3}$ was reduced by 11 and $13.7 \%$, respectively. At the same time, two $\mathrm{AgNO}_{3}$ concentrations induced increase of carbohydrates content in biomass: $0.5 \mathrm{mg} / \mathrm{dm}^{3}$ by $16 \%$ and $1 \mathrm{mg} / \mathrm{dm}^{3}$ by $32 \%$. In case of Cl-free medium (Fig. 5) carbohydrates content was reduced by 17.7 and $32 \%$ at $\mathrm{AgNO}_{3}$ concentrations 0.01 and $0.05 \mathrm{mg} / \mathrm{dm}^{3} . \mathrm{AgNO}_{3}$ concentrations 0.1 and $0.5 \mathrm{mg} / \mathrm{dm}^{3}$ did not influence significantly carbohydrates content, while at silver nitrate concentration $1.0 \mathrm{mg} / \mathrm{dm}^{3}$ carbohydrates content in biomass increased by $19 \%$. Increase of carbohydrates content indicateas on activation of $S$. platensis cells protective function against metal ions toxicity and is the way of its avoidance.

\section{Gold accumulation}

Presence of gold ions in the cultivation medium did not modify essentially the biomass productivity (Fig. 6). In $\mathrm{Na}\left[\mathrm{AuCl}_{4}\right]$ concentration range from 18.5 to $185 \mathrm{mg} / \mathrm{dm}^{3}$ a statistically insignificant decrease of biomass productivity (2-7 \%) was observed. At $\mathrm{Na}\left[\mathrm{AuCl}_{4}\right]$ concentration $370 \mathrm{mg} / \mathrm{dm}^{3}$ biomass concentration was reduced by $18 \%$. It can be concluded that $S$. platensis did not react negatively to the presence of $\mathrm{Na}\left[\mathrm{AuCl}_{4}\right]$ in cultivation medium.

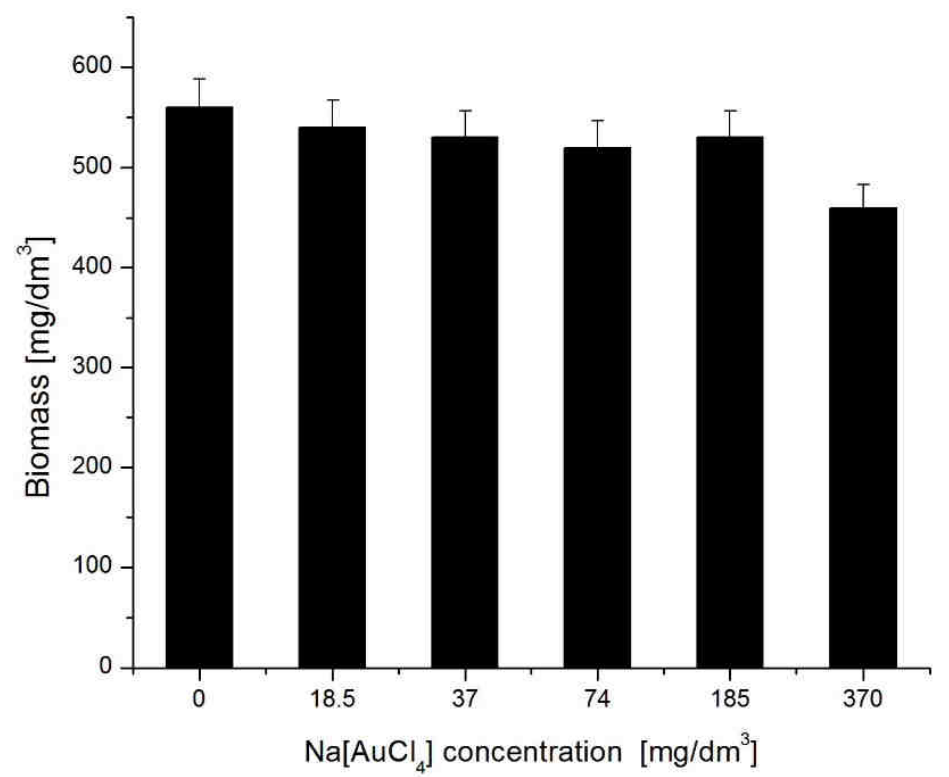

Fig. 6. The effect of different concentrations of $\mathrm{Na}\left[\mathrm{AuCl}_{4}\right]$ on S. platensis biomass productivity (mean $\pm S D, n=3$ )

Gold content in S. platensis biomass changed in a dose-dependent manner. Increase of $\mathrm{Na}\left[\mathrm{AuCl}_{4}\right]$ concentration in solution leads to increase of gold concentration in biomass (Fig. 7). At $\mathrm{Na}\left[\mathrm{AuCl}_{4}\right]$ concentration $370 \mathrm{mg} / \mathrm{dm}^{3}$ gold content in biomass reached the value of $1.0 \mathrm{mg} / \mathrm{g}$. 


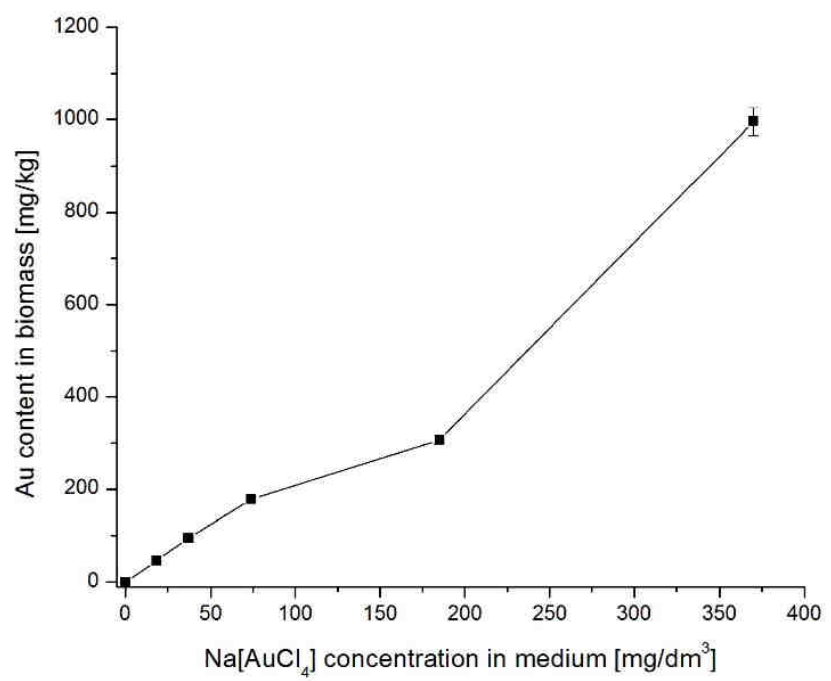

Fig. 7. Gold accumulation by S. platensis biomass determined by neutron activation analysis

Comparing the ability of different microorganisms (bacteria, yeast and cyanobacteria) to uptake gold from gold-thiourea solutions Savvaidis [23] found that cyanobacterium $S$. platensis possesses the highest accumulation of gold from solutions containing $10-50 \mathrm{mg} / \mathrm{cm}^{3}$. Low level of gold accumulated by biomass during the growth process can be explained by activation of systems which protect cyanobacteria cells from excessive accumulation, resulting in low bioaccumulation capacity and/or formation of metal nanoparticles and their further elimination in solution.

Obtained SEM image showed formation of spherical-like nanoparticles on the S. platensis surface (Fig. 8).

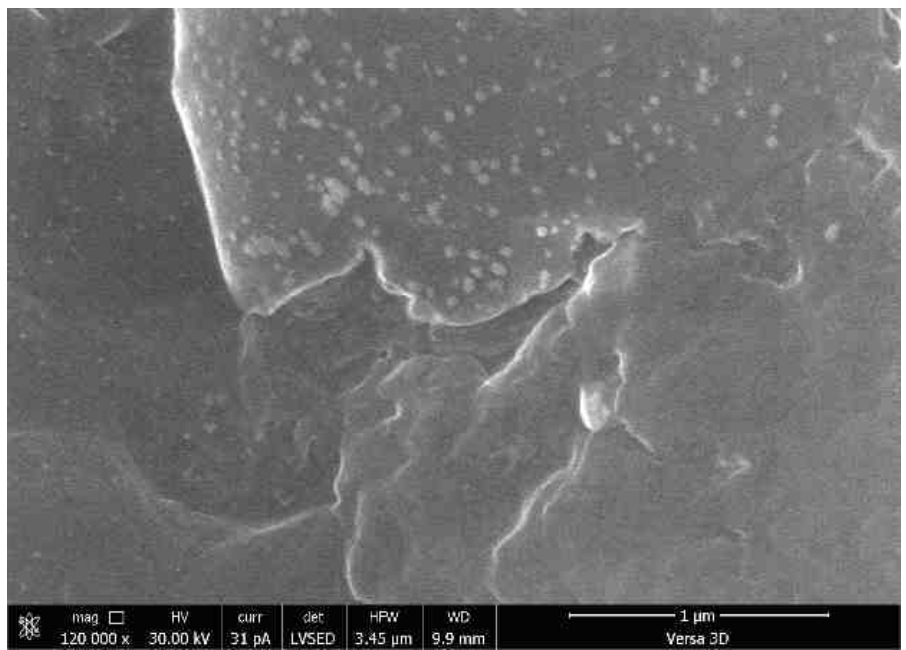

Fig. 8. SEM image of S. platensis biomass with gold nanoparticles after 6 day of cultivation 


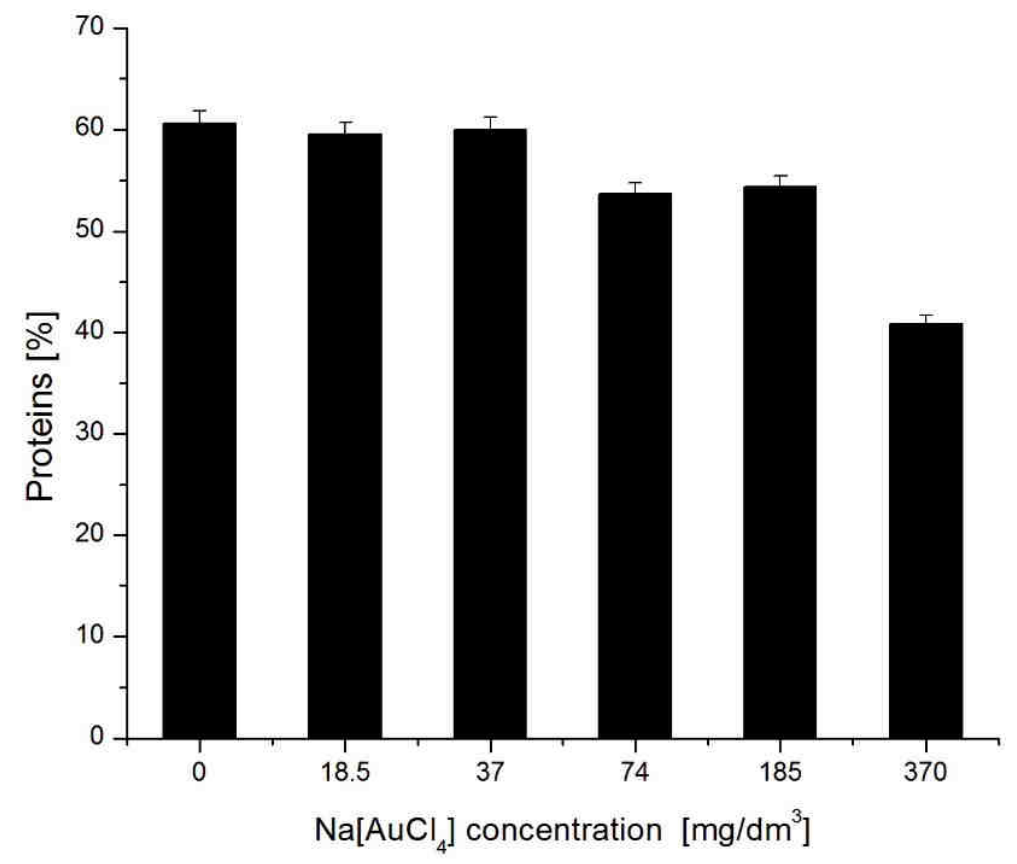

Fig. 9. Proteins content in S. platensis biomass under $\mathrm{Na}\left[\mathrm{AuCl}_{4}\right]$ loading (mean $\pm S D, n=3$ )

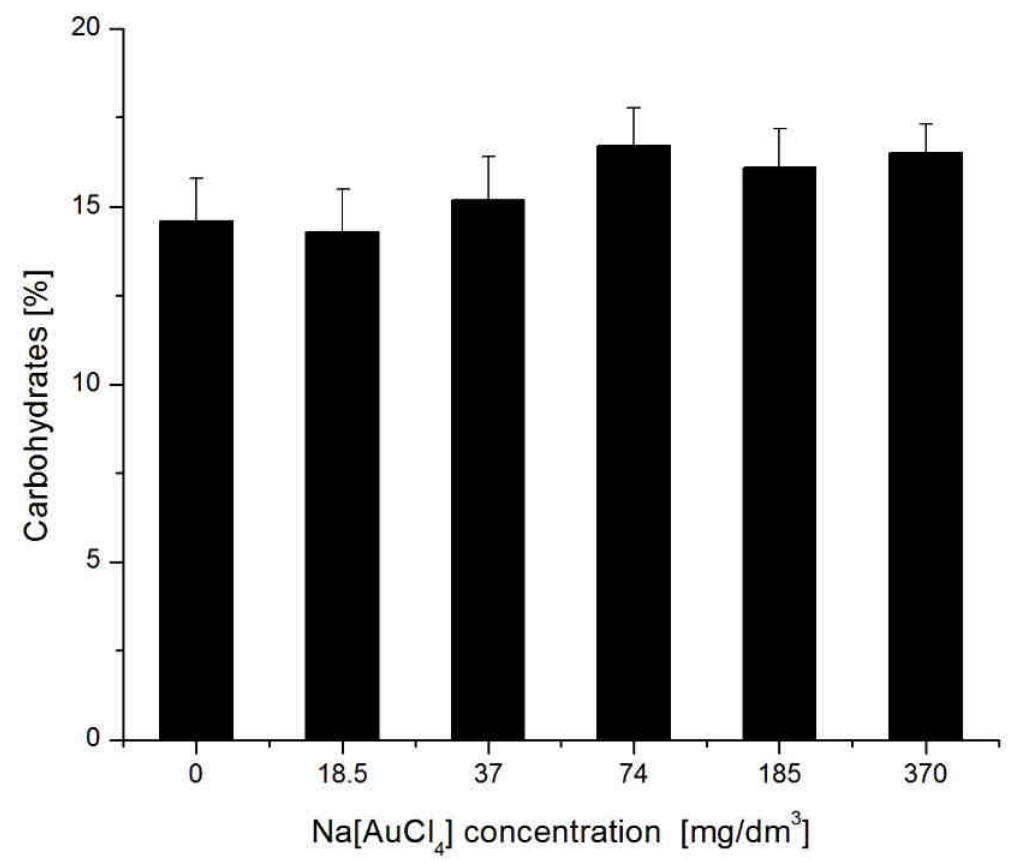

Fig 10. Change of carbohydrates content in S. platensis biomass under $\mathrm{Na}\left[\mathrm{AuCl}_{4}\right]$ loading 
As $S$. platensis is rich in proteins it can be supposed that the process of gold reduction takes place as in case of silver nanoparticles. Lengke et al. [9] studying Au(III) reduction by the cyanobacterium Plectonema boryanum have shown that the reduction of $\mathrm{Au}$ (III)-complex to metallic Au involved the rapid (<2 min) formation of an intermediate $\mathrm{Au}(\mathrm{I})-\mathrm{S}$ species and a slower reductive active pathway to $\mathrm{Au}_{0}$. Similar results were obtained by Reith and co-authors [24], who studied the process of $\mathrm{Au}$ (III) accumulation by Cupriavidu smetallidurans. In case of Acidithiobacillus thiooxidans, gold was reduced to elemental gold within the bacterial cells. During the late stationary growth phase, the gold nanoparticles which were initially precipitated inside the cells were released from the cells, resulting in the formation of gold particles at the cell surface [25].

In the process of gold accumulation, the protein content in $S$. platensis biomass was reduced by 11.3 and $10.1 \%$ at $\mathrm{Na}\left[\mathrm{AuCl}_{4}\right]$ concentration 74 and $185 \mathrm{mg} / \mathrm{dm}^{3}$ (Fig. 9). The highest reduction by $32.4 \%$ was observed at $\mathrm{Na}\left[\mathrm{AuCl}_{4}\right]$ concentration $370 \mathrm{mg} / \mathrm{dm}^{3}$.

In case of carbohydrates, $\mathrm{Na}\left[\mathrm{AuCl}_{4}\right]$ concentrations 18.5 and $37 \mathrm{mg} / \mathrm{dm}^{3}$ induced their decrease by $11.4 \%$ (Fig. 10). At higher $\mathrm{Na}\left[\mathrm{AuCl}_{4}\right]$ concentrations the increase of carbohydrates content in biomass was observed as an indication activation of cell protective function. For example, at $74 \mathrm{mg} / \mathrm{dm}^{3}$ the increase by $13.8 \%$ occurred.

\section{Conclusions}

S. platensis biomass accumulated silver and gold ions in a dose dependent manner. The presence of silver ions affected to a lesser extent biomass productivity in comparison with presence of $\mathrm{AgCl}$ in the cultivation medium. At high silver nitrate concentrations in solution the reduction of biomass productivity and protein content was observed, while the content of carbohydrate increased. In case of $\mathrm{Na}\left[\mathrm{AuCl}_{4}\right]$ the decrease of biomass productivity and protein content was noticed only at concentration $370 \mathrm{mg} / \mathrm{dm}^{3}$. The carbohydrate content did not change significantly after 6 days of cultivation. A part of bioaccumulated silver and gold ions were bioreduced to nanoform. S. platensis biomass can be used for precious metal recovery from effluents that are not economically beneficial by conventional techniques.

\section{References}

[1] He J, Kappler A. Recovery of precious metals from waste streams. Microb Biotechnol. 2017;10:1194-1198. DOI: $10.1111 / 1751-7915.12759$.

[2] Dominguez-Benetton X, Varia JC, Pozo G, Modin O, Ter Heijne A, Fransaer J, et al. Metal recovery by microbial electro-metallurgy. Prog Mater Sci. 2018;94:435-461. DOI: 10.1016/j.pmatsci.2018.01.007.

[3] Schippers A, Hedrich S, Vasters J, Drobe M, Sand W, Willscher S. Biomining: metal recovery from ores with microorganisms. Adv Biochem Eng Biotechnol. 2014;141:1-47. DOI: 10.1007/10_2013_216.

[4] Chojnacka K. Biosorption and bioaccumulation - the prospects for practical applications. Environ Int. 2010;36:299-307. DOI: 10.1016/j.envint.2009.12.001.

[5] Zinicovscaia I, Safonov A, Tregubova V, Ilin V, Cepoi L, Chiriac T, et al. Biosorption and bioaccumulation of lanthanum, chromium, vanadium and uranium from single and multi-component batch systems by Arthrospira (spirulina) platensis biomass. Ecol Chem Eng S. 2016;23:401-412. DOI: 10.1515/eces-2016-0028.

[6] Zinicovscaia I, Safonov A, Tregubova V, Ilin V, Frontasyeva MV, Demina L. Bioaccumulation and biosorption of some selected metals by bacteria Pseudomonas putida from single- and multi-component systems. Desalin Water Treat. 2017;74:149-154. DOI: 10.5004/dwt.2017.20732.

[7] Govindaraju K, Basha SK, Kumar VG, Singaravelu G. Silver, gold and bimetallic nanoparticles production using single-cell protein (Spirulina platensis) Geitler. J Mater Sci. 2008;43:5115-5122. DOI: 10.1007/s10853-008-2745-4. 
[8] Correa-Llantén DN, Muñoz-Ibacache SA, Castro ME, Muñoz PA, Blamey JM. Gold nanoparticles synthesized by Geobacillus sp. strain ID17 a thermophilic bacterium isolated from deception Island, Antarctica. Microb Cell Fact. 2013;12:75. DOI: 10.1186/1475-2859-12-75.

[9] Lengke MF, Ravel B, Fleet ME, Wanger G, Gordon RA, Southam G. Mechanisms of gold bioaccumulation by filamentous cyanobacteria from gold(III)-chloride complex. Environ Sci Technol. 2006;40:6304-6309. DOI: 10.1021/es061040r.

[10] Solisio C, Lodi A, Soletto D, Converti A. Cadmium biosorption on Spirulina platensis biomass. Bioresour Technol. 2008;99:5933-5937. DOI: 10.1016/j.biortech.2007.11.002.

[11] Arunakumara KKIU, Zhang X, Song X. Bioaccumulation of $\mathrm{Pb}^{2+}$ and its effects on growth, morphology and pigment contents of Spirulina (Arthrospira) platensis. J Ocean Univ China. 2008;7:397-403. DOI: 10.1007/s11802-008-0397-2.

[12] Frontasyeva MV. Neutron activation analysis in the life sciences. A review. PEPAN. 2011;42:332-378. DOI: 10.1134/S1063779611020043.

[13] Pavlov SS, Dmitriev AYu, Frontasyeva MV. Automation system for neutron activation analysis at the reactor IBR-2, Frank Laboratory of Neutron Physics, Joint Institute for Nuclear Research, Dubna, Russia. J Radioanalyt Nuclear Chem. 2016;309:27-38. DOI: 10.1007/s10967-016-4864-8.

[14] Ghandour W, Hubbard JA, Deistung J, Hughes MN, Poole RK. The uptake of silver ions by Escherichia coli K12: Toxic effects and interaction with copper ions. Appl Microbiol Biotechnol. 1988;28:559-565. DOI: $10.1007 / \mathrm{BF} 00250412$.

[15] Slawson RM, Van Dyke MI, Lee H, Trevors JT. Germanium and silver resistance, accumulation, and toxicity in microorganisms. Plasmid. 1992;27:72-79. DOI: 10.1016/0147-619X(92)90008-X.

[16] Erickson RJ, Brooke LT, Kahl MD, Venter FV, Harting SL, Arkee TPM, et al. Effects of laboratory test conditions on the toxicity of silver to aquatic organisms. Environ Toxicol Chem. 1998;17:572-578. DOI: 10.1002/etc.5620170407.

[17] Reinfelder JR, Sung IC. Speciation and microalgal bioavailability of inorganic silver. Environ Sci Technol. 1999;33:1860-1863. DOI: 10.1021/es980896w.

[18] Fortin C, Campbell PGC. Silver uptake by the green alga Chlamydomonas reinhardtii in relation to chemical speciation: influence of chloride. Environ Toxicol Chem. 2000;19:2769-2778. DOI: 10.1002/etc.5620191123.

[19] Cepoi L, Rudi L, Chiriac T, Valuta A, Zinicovscaia I, Duca G, et al. Biochemical changes in cyanobacteria during the synthesis of silver nanoparticles. Canad J Microbiol. 2015;61:13-21. DOI: 10.1139/cjm-2014-0450.

[20] Tsibakhashvili NY, Kirkesali EI, Gintury E, Pataraya D, Gurielidze M, Kalabegishvili T, et al. Microbial synthesis of silver nanoparticles by Streptomyces glaucus and Spirulina platensis. Adv Sci Let. 2011;4:3408-3417. DOI: 10.1166/asl.2011.1915.

[21] Li X, Xu H, Chen ZS, Chen G. Biosynthesis of nanoparticles by microorganisms and their applications. J Nanomater. 2011; 1-16. DOI: 10.1155/2011/270974.

[22] Kalishwarala K, Deepak V, Ramkumarpandian S, Nellaiah H, Sangiliyandi G. Extracellular biosynthesis of silver nanoparticles by the culture supernatant of Bacillus licheniformis. Mater Lett. 2008;62:4411-4413. DOI: 10.1016/j.matlet.2008.06.051.

[23] Savvaidis I. Recovery of gold from thiourea solutions using microorganisms. Biometals. 1998;11:145-51. DOI: $10.1023 / \mathrm{A}: 1009234113485$.

[24] Reith F, Etschmann B, Grosse C, Moors H, Benotmane MA, Monsieurs P, et al. Mechanisms of gold biomineralization in the bacterium Cupriavidus metallidurans. Proc Natl Acad Sci USA. 2009;106:17757-17762. DOI: 10.1073/pnas.0904583106.

[25] Lengke MF, Southam G. The Effect of thiosulfate-oxidizing bacteria on the stability of the gold-thiosulfate complex. Geochim Cosmochim Acta. 2005;69:3759-3772. DOI: 10.1016/j.gca.2005.03.012. 